Article

\title{
Play, Game, and Videogame: The Metamorphosis of Play
}

\author{
Javier Gil-Gimeno * (1), Celso Sánchez-Capdequí (1) and Josetxo Beriain (1) \\ Department of Sociology, Public University of Navarra, Campus Arrosadia s/n, 31006 Pamplona, Spain; \\ celso.sanchez@unavarra.es (C.S.-C.); josetxo@unavarra.es (J.B.) \\ * Correspondence: fcojavier.gil@unavarra.es
}

Received: 2 April 2018; Accepted: 12 May 2018; Published: 17 May 2018

\begin{abstract}
The question, the Fragestellung, which drives this paper is, can football video-games be analyzed from a religious perspective? We can answer positively, at least, provisionally. First, in order to demonstrate our approach, we will take into account the different conceptions on play drawn along sociological theories. Second, we will analyze Francis M. Cornford's contribution to the already forgotten but essential work by Jane Ellen Harrison, Themis: The Social Origins of the Greek Religion, in which he established an elective affinity between the origin of the Olympic Games and the annual ritual dedicated to the Daimon-God Dionysus, in which he was elected the best Kouros (Young hero-King) of the year. At the very beginning, play, ritual, and competitive games (helped by self-reflexivity as well as collective reflexivity) were united, and that constellation is still there in modern times with the creation of modern sport. Third, in modern advanced societies the football game-sport creates meaning, and succeeded throughout two main processes such as the sportification and progressive rationalization of violence. Fourth, we built an ideal type of two competing strategies, in which created a new type of hero, the sports hero, the modern celebrity. Finally, fifth, we analyze how in our digitalized societies the football videogames are a sort of play on the play of which comes out a religious transcendence associated with it, "Throughout the videogame I become myself in my idol". We explain this comparing two ideal types, the Dionysian-Messi versus the Apollonian-Ronaldo.
\end{abstract}

Keywords: play; game; football videogames; religion; ritual practices

\section{Introduction}

Play is one of the many realities that shape the world. One might even say it constitutes a world within the world, since it predates human culture. Animals played long before humans did. What is striking is that, amongst animals whose social structure with a varying degree of strong hierarchy, such as canines and primates, play is characterised by a sense of parity. Indeed, its purpose is to reduce inequalities associated with size, strength and social status. Play is egalitarian. Here, one can see a certain notion of justice, there is a series of rules and expectations that help neutralise the differences between individual animals, intended to maintain the harmony of the group (Bekoff and Jessica 2009, p. 121). Neither homo erectus nor their successor, homo sapiens, can equal the strength or speed of animals; nor can they match their skill at climbing trees or manipulating objects with their feet. Nonetheless, they have surpassed them by developing novel, speedy body postures and complex gestures, which can be used in dance, swimming, gymnastics, tool-building, mime, and gesture. What is truly surprising about the emergence of this new set of evolutionary skills, however, is that, although the product of imagination and learning, they are paradoxically manifested as the outcome of a useful uselessness of the immature. That is to say, these actions, which are functionally and pragmatically useless (either to children or to adults) are distinctively human and profoundly valuable (useful). 
There are times and places in which "Human beings don't live in the real world" (Gopnik 2009, p. 19), such that they create a separate space-time, a world outside that other serious and pragmatic world of the everyday. This is the world of play.

\section{An Analytical Vision of Play}

In a work that had great sociological influence, George Herbert Mead [1934] (1962, pp. 152-64) introduced a crucial distinction between unregulated play and the regulated game. The aim of play, developed spontaneously by children, is to maximize pleasure. In the game, in contrast, the child-and by extension the adult-adopts the same attitude as everyone else involved in the same game. That is to say, he follows the rules of the game, in the terms established by Ludwig Wittgenstein (1988, p. 74). This attitude finds its expression "in taking the role of the other, playing at the expression of their gods and their heroes, going through certain rites which are the representation of what these individuals are supposed to be doing. The process is one which develops, to be sure, into a more or less definite technique and is controlled" (Mead [1934] 1962, p. 153). In accepting the roles of the others, players assume what is expected of them in their role and in their relation to the shared collective goal. They fully adopt and accept the organized guidelines of the team or the ensemble, which are born out of the 'generalized other' as a single entity to which the players belong, thus creating an 'us', an esprit de corps. In order to play in a team, the child must move from specific thought to abstract thought, allowing him or her to accept the rules not as 'mine', or 'yours', but as 'ours'. Whereas the search for pleasure is egocentric, directed at oneself, the search for group recognition and the collective excitation generated by the game among the spectators is directed at others (Elias and Dunning 1992, p. 251).

We have seen how play transgresses the limits of pure biology and physics, creating a sense, a meaning. By exceeding the bounds of the biological 'instinct', it creates a novel instance, the 'spirit'. As Johan Huizinga says in his Homo Ludens: "In the making of speech and language the spirit is continually 'sparking' between matter and mind, as it were, playing with the wondrous nominative faculty. [ ... ] Thus, in giving expression to life man creates a second, poetic world alongside the world of nature" (Huizinga [1949] 1980, p. 4). However, before trying to define what play is, we should first establish what it is not. Play is not opposed to the serious; a child who plays does so seriously. Although one part of unregulated play provokes laughter that does not mean that they are the same. Nor should play be identified with the comic, which is related to the foolish, basically because play is not foolish. According to J. Huizinga [1949] (1980), it is a free activity, it is freedom. Play is not coercively activated. It represents a certain suspension of 'ordinary' life, a supra-logical counter-world, which transcends the logic of the normal-serious world, an interlude in everyday life. It creates its own space and its own time and generates an order that is parallel to (and, sometimes, in conflict with) the common order, as is the case with the carnival/Mardi-Gras celebration. In the game there is a clear tension, a sense of chance, uncertainty, contingency, or puzzle, all of which have to be confronted with bodily strength, stamina, inventiveness, daring, and cunning. When two contending groups (i.e., two teams) come together, this is manifested as a struggle, a fight between two polarities to which violence is progressively sublimated to become contest in pursuit of triumph and/or the breaking of a record.

Child's play is the most elementary form of play, but, as G. H. Mead has shown, it is transformed into more complex forms of game. As J. Huizinga puts it: "Archaic society, we would say, plays as the child or animal plays. Such playing contains at the outset all the elements proper to play: order, tension, movement, change, solemnity, rhythm, rapture. Only in a later phase of society is play associated with the idea of something to be expressed in and by it, namely, what we would call 'life' or 'nature'. Then, what was wordless play assumes poetic form. In the form and function of play, itself an independent entity which is senseless and irrational, man's consciousness that he is embedded in a sacred order of things finds its first, highest, and holiest expression. Gradually the significance of a sacred act permeates the playing. Ritual grafts itself upon it; but the primary thing is and remains play" (Huizinga [1949] 1980, pp. 17-18). As we shall explain in greater detail, using the evolutionary methodology developed by Merlin Donald (1991), the mimetic-imitative aspects of 
play are gradually complemented by higher and more advanced mythical-symbolic and theoretical forms. In other words, "in myth and ritual the great instinctive forces of civilized life have their origin: law and order, commerce and profit, craft and art, poetry, wisdom and science. All are rooted in the primeval soil of play" (Huizinga [1949] 1980, p. 5). 'The sacred' does not exist as a prior idea or belief in mysterious or supernatural beings; instead it is only through ritual that it comes into existence. The existence of 'the sacred' precedes the essence-belief in the sacred: "Only through the appropriating event of the ritual does the sacred (and its figures: demons, gods and men) emerge as something different to the secular." (Beriain 2015, pp. 4-7).

The act of ritual communion clearly unifies the group, but around what? Action, emotional energy, and shared feelings cannot be sustained for long when they are activated merely by constituting an intensification of the collective existence. It is here that society itself intervenes through a process of symbolic sublimation in which the symbol is objectivized. As G. H. Mead [1934] (1962) notes, the symbol is the mark of the transition from pure biological stimulus to symbolic re-presentation. It is an immensely consequential evolutionary feat, since it transforms the mimetic action into symbolic action, "thus extending the lifetime of ritually intensified sentiments" (Collins 2004, p. 34). Indeed, "Social sentiments could have only a precarious existence. Though very strong as long as men are together and influence each other reciprocally, they exist only in the form of recollections after the assembly has ended, and when left to themselves, these become feebler and feebler; for since the group is now no longer and active, individual temperaments easily regain the upper hand [ ... ] Thus these systems of emblems, which necessary if society is to become conscious of itself, are no less indispensable for assuring the continuation of this consciousness" (Durkheim [1912] 1965, p. 263). The intention is to celebrate the solidarity of the group, attending to the sentiments of all its members and, probably, marking the identity of the group in opposition to others. In-group solidarity and out-group solidarity are human options that recur at all levels, e.g., in hunters and gatherers, groups of schoolchildren, football teams, and even nation-states. There are innumerable references to play in sacred texts, but both J. Huizinga [1949] (1980) and Robert N. Bellah in his latest work (Bellah 2011, pp. 109-10) view the Second and Seventh books of Plato (1980) Laws as the most relevant observations on play and its capacity to mediate domains of meaning, the sacred and the secular, and on the figures involved, gods and men. In the Second book, Plato explains the value of festivals and links their origin to children's play:

"This education [based on the proper ordering of passions in childhood] which consists in correctly trained pleasures and pains tends to slacken in human beings, and in the course of a lifetime becomes corrupted to a great extent. So, taking pity on this suffering that is natural to the human race, the gods have ordained the cycle of festivals as times of rest from labour. They have given as fellow celebrants the Muses, with their leader Apollo, and Dionysus -in order that these divinities might set humans right again. Thus, men are sustained by their festivals in the company of gods" (Plato 1980, p. 36).

Finally, this passage from Book VII highlights the importance of play for Plato in the origin of ritual and myth:

"I say that man must be serious with the serious. God alone is worthy of supreme seriousness, but man is made God's plaything, and that is the best part of him. Therefore, every man and woman should live life accordingly and play the noblest games and be of another mind from what they are at present [ ... ] For they deem war a serious thing, though in war there is neither play nor culture worthy the name which are the things we deem most serious. Hence all must live in peace as well as they possibly can. What, then, is the right way of living? Life must be lived as play. Playing certain games, making sacrifices, singing and dancing, and then a man will be able to propitiate the gods, and defending himself against his enemies and win in the contest" (Plato 1980, p. 193). 


\section{From Play and Ritual Practice in the Social Genesis of the Olympic Games to Modern Sport}

Without losing sight of the fact that ritual is itself no more than an evolved form of serious play-that is to say, a game-let us now examine the Hymn of the Kouretes in Ancient Greece. This will enable us to analyse ritual as that complex form of game, whose rationalized version was originally represented by the Olympic Games. The Hymn was the founding landmark or appropriating event, which we can use to identify the social genesis of the game. The Hymn of the Kouretes (Harrison 1912, pp. 1-29) provides an example of that primitive rite of tribal initiation (Eniautos-Daimon) (Harrison 1912, p. 16), which performatively expresses the Greek worldview. Based on archaeological findings, Jane E. Harrison recovers the syntax of ritual and explores its profound interpretative meaning. The Hymn comprises three phases (Harrison 1912, p. 9 and following). In the first phase, the invocation, the god-originally Dionysus and later Zeus-is challenged as an immortal child or Kouros. In the second phase, ritual performativity, the participants (Kouretes), armed with shields and in an emotional frenzy, tear the child from his mother, conceal him, 'kill' him, cut him to pieces and scatter his remains to the wild ${ }^{1}$. Finally, in the third phase, the child reappears, he is brought back to life, revived and becomes the bearer of the collective wellbeing.

Let us now examine how the religious character underlying the origins of the ancient Olympic Games (those staged between 776 and 393 BC) first arose. British philologist Francis M. Cornford contributed a chapter to Harrison's (1912) study on the origins of the Olympic Games in Classical Greece, which we will use to help focus our study. Cornford sets out two ideas that are fundamental to understanding the religious origin of the games: firstly, the link with a festival held to honour Dionysus and later Zeus, and second, the subsidiary role played by the sporting competition in this celebration. We shall examine these two ideas together.

As F. M. Cornford notes, in their origins, the Olympic Games were not associated with the festival as a whole, nor with its overall significance, but merely with a specific part, i.e., the annual selection of the "Kouros" or best of the young men. As part of the ritual festival, a race was held to choose this 'best among the young men', who would subsequently be honored with the singing of the Hymn of the Kouretes, accompanied by a ritual dance. These, then, are the origins of the Olympic Games. Essentially, there were two privileges associated with victory in the race to choose the Greatest Kouros. Firstly, the right to hold the title for a year (or a given period), ${ }^{2}$ showing a clear continuity between this event and the festival related to the rebirth of the Eniautos-Daimon or annual spirit. The winning kouros was reborn as an adult being who could participate in society and, thanks to his victory, play a key role in it. The second privilege was associated with that role. The year's kouros was charged with heading the procession in which the community led a sacrificial bull to the altar of the god, where the central part of the rite was performed.

So, as F. M. Cornford says, "Had we begun this chapter with the statement that the triumphal procession, or komos, was the original kernel of the Olympic Games, it would have seemed, in the strict sense of the word, preposterous. But in view of the facts we have analysed and of the previous discussion of the Dithyramb (p. 205), it will not perhaps now seem paradoxical to suggest that this procession, with its sacrifice and eating of a bull, its hymn to the hero, and the concluding feast in the banqueting chamber, was the central rite, to which the foot-race of the Kouretes was a mere preliminary". (Cornford 1912, p. 256). As J. Huizinga rightly notes, "The rite is a dromenon, which means 'something acted', an act, action. That which is enacted, or the stuff of the action, is a drama, which again means act, action represented on a stage. Such action may occur as a performance or a contest" (Huizinga [1949] 1980, p. 14). The cult is a dramatic representation. Indeed, "At the great

1 Note the parallels between the dismembering and the subsequent recreation in nature found in the Hymn of the Kouretes and the figure of Dionysos/Zagreo in Euripides' Bacchae, which follows the same mythological narrative.

2 Although we do not know with certainty whether the rite was held every year, the victor held the title of Kouros for a specific period of time. 
seasonal festivals the community celebrates the grand happenings in the life of nature by staging sacred performances, which represent the change of seasons, the rising and setting of the constellations, the growth and ripening of crops, birth, life and death in man and beast". (Huizinga [1949] 1980, p. 15).

Originally in the Olympic Games, which began with a foot race "for the kingdom" (Cornford 1912, p. 255), the Kouros of the Cretan Hymn analyzed here is depicted as the leader of his daimons. "The race, whose original purpose was simply to determine who should be the greatest Kouros or King of his year, developed by successive accretions into the elaborate athletic sports, which in later times came to be the central feature of the whole festival" (Cornford 1912, p. 256). Long Live King Heracles (Hercules)! He is the Daimon embodied in the winner of the race who, to a great extent, stands as the object of worship. The Olympic victor was the daimon of his year, the local hero and king (Cornford 1912, pp. 256-57) of the games, normally held in spring. In Cornford's explanation, we can clearly see the process whereby the part is substituted for the whole, where a single section of the original religious rite- the foot race to choose the Kouros of the year-mutates into a lay ritual ceremony converted into a global mass phenomenon, i.e., the modern Olympics. As Cornford himself says, "The race, whose original purpose was simply to determine who should be the greatest Kouros or King of his year, developed by successive accretions into the elaborate athletic sports, which in later times came to be the central feature of the whole festival" (Cornford 1912, p. 256), it becomes a competitive de-ritualized Olympic, act.

J. Huizinga identifies two levels of play in social life. One lies below the threshold of consciousness and is dominated by an "only pretending" (Huizinga [1949] 1980, p. 8) that forges reality. In another, conscious level, the skill and determination inherent to precarious social balances are regulated. In Huizinga's words, "In play we may move below the level of the serious, as the child does; but we can also move above it-in the realm of the beautiful and the sacred" (Huizinga [1949] 1980, p. 19).

Since time immemorial, its presence has formed part of the unwritten history of humankind in which the conditions of human representation and their mother element, theory, are forged. Play-and more specifically, its primordial version, the rite understood as a rhythmic, ensemble, and coordinated expression of dramatic movements constituting ordered coexistence-is established in the pre-narrative substratum as a pattern for ordering a human life which is born prematurely and without instinctive specialisation (Gehlen 1980, p. 150). Ritual play lays the foundations for a forced creativity to which the human condition is called due to its congenital plasticity and existential opening. The basis of the game as a tool for creating social order in the absence of the theoretical guidelines of superior knowledge is the emotional agitation caused by a nature that confers on man an instinctive, precarious, and barely mature skillset. This is translated into a life experience centring on "an unlimited field of surprise, in which the first thing that is needed is some orientation" (Gehlen 1980, p. 151). Such orientation cannot be achieved from the underlying agitation and can only be channelled by an external instance regulating social behavior. The connatural in-adaptation of man to the world expressed in an overabundance of weak instincts and a boundless hyper-stimulation leads to the formation of mechanisms for coordinating action and attention based on the emergence of institutions that regulate uncertain behaviour. In the presence of superior thinking, man urgently needs to determine existential indeterminacy.

The Canadian psychologist Donald (1991) provides an explanatory framework in which play contributes to the formation of human consciousness. He describes evolution and the acquisition of skills without resorting to the classic notion of evolutionism centring on selection of the species. Donald proposes a non-evolutionist vision of evolution in which the acquisition of new faculties and skills does not result in the disappearance of earlier ones. The emergence of new faculties signifies an internal reorganisation of the overall picture of human representations and the possibility that in specific historical episodes, one may predominate over the rest without this involving deterministic and finalistic explanations. "The modern mind is thus a hybrid structure containing vestiges of earlier stages of human emergence, as well as new symbolic devices that radically altered its organization" 
(Donald 1991, p. 4). In any case, the course of events does not follow a deterministic pattern based on the notion of need.

Donald offers an evolutionary approach based on four cultural phases: episodic, mimetic, mythic, and theoretic culture. Each one is integrated into, and enriches, the next. As R. N. Bellah, one of the sociologists most closely associated with Donald's thinking, puts it, "nothing is ever lost" (Bellah 2011, p. 72). Thus, we can see the metamorphosis of play, born as an imitative process tending to self-satisfaction, and transformed, thanks to the invention of human symbolic and narrative capacity, into a ritually regulated game, which is in turn transformed through sporting rationalization in modern societies into a scientific and technically perfected game, which still retains both its ritual and its imitative dimension. It may change, and, indeed, the rules and styles of play, and even the associated rituals, do change. However, what does not disappear is the game as such.

At the same time, the sports modulate their own self-image with the help of design, fashion, and advertizing. For in its narrative, the myth extols certain actors and feats from social life. It remains present in the narratives, chronicles, and legends which shape that world and which satisfy the contemporary actor's need for a dialogue with figures and archetypes that go beyond the routine bounds of everyday life. Players of football or any other sport are the new expressions of a secular sanctity, which depicts symbolic features of the human adventure, such as challenge, ambition, frustration, etc. The accounts of universal religions have not disappeared, but they are no longer the only ones. They are accompanied by secular myths, which emphasise the limits of existence. Now, however, they have a new and previously unknown element-self-reflexivity-which translates not only into a ritual secular game organized from human reasoning for an audience in need of new shared hopes, but also into the possibility (now clearly consummated) that the spectators themselves can form part of the game. In this new space of global interaction of individual virtual games, they no longer merely observe, they also act out being like the player who best matches their view of the world, which is the case of the real player on the videogames. In contrast to the collective mythifications, individual self-mythifications arise which are again capable of balancing forces and reducing the differences between competitors. This dissolving of differences is the result of virtual technology, which transforms the playing field in that its limits are not established by divine imposition, but by individual will. It is that will that decides what match is to be played, who the teams will be, what kit they will wear and how long the match will last. In short, the myth has been opened up to multiple uses. No longer is it managed by a centralized authority, but by the imagination of the actors. In a way, the individual participates in the new myths of football. He or she recreates them. Individuals see themselves as being a central part of the myth. They no longer act out founding scenes of the community, they represent themselves by re-enacting them.

\section{Football, Industrialisation and the 'Sportification' of Play: The Social Genesis of Football as a Modern Sport}

Both the Industrial Revolution of the mid-eighteenth century and the notion of introducing games as a regular extra-curricular activity in private schools (as promoted by Thomas Arnold in 1830), gave a clear incentive to the large-scale development of sport throughout the Victorian era in England. This was followed, in the late nineteenth and early twentieth centuries, by the restoration of the Olympic Games in Athens (1896) and a reawakened interest in nearly all competitive sports, including football (Elias and Dunning 1992, p. 162). In their magnificent studies of the evolution of sport and, more specifically, of football at the end of the Middle Ages and the beginning of the Modern Age in England, N. Elias and Eric Dunning point to the dual process whereby on the one hand, a rural population of peasants in different degrees of servitude were transformed into more or less free peasants and, on the other, a new class of untitled landowners arose, forming what became known as the gentry (Elias and Dunning 1992, p. 227).

It was in this context that the game (specifically football) emerged, as a local entertainment for a population of more or less free peasants, sponsored by local landlords, who were not always 
members of the nobility. There was no national framework of competition because the state was relatively unformed in the development of late-seventeenth and early eighteenth century British society, and the aristocracy and gentry 'were the State', using its apparatus to serve their own interests. Industrialization, combined with a new strengthening of the state, broke down this dynamic. The result was greater pressure to create forms of sports participation targeted not at a local, but a national audience, and oriented towards victory or the overcoming of records. There was a major shift from amateur to professionalized sport, which progressively broke through national barriers and took on a global perspective (Elias and Dunning, pp. 247, 262-63). However, there was no single reason for this transformation and rationalization in sport, but a set of different factors.

Another was clearly the 'sportification' of the pastime (Elias and Dunning 1992, p. 34), in other words, the transformation of the pastime into sport, practised in the spare hours not devoted to waged labour. Such activities, which included horse racing, tennis, boxing, athletics races, football, and rugby, required players to perform methodical exercise to keep fit. A whole series of new rules and means of arbitrations had to be introduced to ensure fair play and increase the competitiveness of the competing teams.

The emergence of sport as a physical struggle - as against the traditional agonal struggle-is associated with the pacification of cycles of violence (Elias and Dunning 1992, p. 39). It brought an end to factional and sectarian fighting. Contributing to this development was the triumph of a unique social formation, the English gentry, together with new forms of parliamentary government based on democratic debate, in other words, on the game of political persuasion. Another contributing factor was undoubtedly the monopolization and relatively solid, stable and impersonal control of the means of violence by emerging nation-states (Fukuyama 2018, pp. 15-25) contrasting with traditional agonal forms of struggle, one of whose most characteristic examples is the Spartan pancration, where adversaries fought with their whole bodies-hands, feet, elbows, knees, neck, head, and even teeth. 'Pancratiasts' were even allowed to gouge out their opponents' eyes. They could trip them up, take hold of their noses, feet, or ears, dislocate their fingers and arms, and even use strangleholds. The wrestlers suffered terrible injuries, and some died as a result. The most brutal of games was that played by the epheboi of Sparta (Dress 1968, p. 83).

As for the meaning and structure of football, there are Marxist writers, such as Bero Rigauer (1969) who argue that in industrialized societies, sport is increasingly characterized by a quest for successes, reflected in a tendency to beat records, incited by the 'bourgeois spirit' of the dominant class, which seeks to commercialize the area of leisure and recreation. Other authors, such as Gregory P. Stone (1971) argue that all sports are affected by two opposite principles, play and exhibition. The problem arises, according to Stone, when the exhibition-oriented towards spectators or viewers—ends up destroying the recreational nature of sport. This is what has happened in the case of the Harlem Globetrotters, a basketball team known not for their titles, but for their exhibition matches. Although the two approaches illuminate important dimensions of the game, they do not get to the heart, the core, of a modern sport such as football. We believe that the concept of "balance of dichotomous tensions" coined by Elias and Dunning (1992, p. 250) and by Dunning (2009, pp. 15-27) accurately stresses the basic meaning of the game, by placing it within the dynamic tension (in-group versus out-group) (Elias and Dunning 1992, p. 268), i.e., between two players or groups of players at once antagonistic and interdependent within a double mutual contingency. There are a number of polarities, which take place in and through the game. Chief among them are the polarities between opposing teams, between attack and defence, between cooperation and tension between the two teams, between cooperation and competition within each team, between an emotional identification with one's own team and rivalries with the opposition, between individual aggression and the restraining of such aggression by the rules, between performance and results, between game and mass spectacle, or between players (the game) and managers (money-business).

The key of sports in general and of football in particular would be in the unloading of our energy and in the concomitant projection of energy towards the world. Thus, our own personal unloading 
of energy brings about the energy reloading of the other as observer, emerging as a result of that a dynamic loop between the player and the co-player, between the football players and the public, between the team and its symbolic equipment. All teams symbolize with their 'colours' to the people to whom are referred, to the clan or tribe with their attributes, to the daimon-spirit of the place. Thus, the Athletic of Bilbao has a Basque symbology, the Barça has a Catalan symbology, and the Real Madrid has a central or Castillian, Spanish or universal symbology, as has the Spanish language. Today, the Real Madrid would be a symbol of Spain, which floats in its own turbulences, a symbolism which personifies at best the "madridista" supporter and tennis player, Rafael Nadal.

One undoubtedly relevant factor in the development of football as a mass phenomenon has been its 'functional democratization'. In a process that began in the North and Midlands, lower status (middle and working class) organizers, players, and spectators emerged, breaking the monopoly of the "public school élite" (Elias and Dunning 1992, p. 260) of the country's ruling class. A new inter-class ethic of amateur sport began to take hold, increasingly existing alongside professionalising sport.

The increase in the size of the social conglomerates-cities, noted by Herbert Spencer, favored the creation of "chains of interdependence", greater connectivity between individuals and between social circles, as Émile Durkheim noted. This created a modern structure of social interdependence, which at the same time generated a demand for interregional, national, and transnational sport. But, unlike Elias and Dunning (1992) who believe that in today's culture, sport is ultimately developing towards record-beating and pure performance, we do not believe that there is any such ultimate and one-way trend towards seriousness (Huizinga [1949] 1980), nor do we feel that sport should be seen as something bourgeois, or class-based (Rigauer 1969). Rather, there subsists a dynamic tension between opposing forces, between game and performance, between amateur and professional, between art in motion and pure technique.

In the first part of this paper, we analyzed the emergence of the hero in the competitive game, identified in ritual practice with the daimon, with the magic potential, embodied by the group, to later become an Olympic God. We shall now take a last methodological step by analyzing the play on play of football video games. We shall compare two currently opposing ideal types, the Dionysian model of the trickster Lionel Messi and the new Apollonian Herakles, embodied by Cristiano Ronaldo.

\section{Football and the Sacred. Cristiano Ronaldo and Lionel Messi as Weberian Ideal Types}

Michel Maffesoli remarks that footballers are "emblematic figures" (Maffesoli 2009, p. 204) of postmodern societies. An emblem is "a symbol or representation typifying or identifying an institution or quality, etc." (Concise Oxford Dictionary of Current English (Oxford Dictionaries 1992, p. 381)). In Elementary Forms of Religious Life (Durkheim [1912] 1965), É. Durkheim presents the emblem as being closely related to the religious in totemic societies. Based on our deliberations above, we shall now analyze whether behind the footballer, viewed as an emblematic figure, it is possible to see some type of religious component.

In order to continue conceptually furnishing this issue we shall examine another of the classical studies on the origins of religion, Wilhelm Wundt's Elements of Folk Psychology, first published in 1912. W. Wundt establishes three figures or forms directly linked to the religious in what he calls the 'primitive man' stage: demons, heroes, and gods, and he describes the relationships of cause and effect between them. What differentiates a god or hero from a demon is that the latter is an impersonal force, it "lacks the attribute of personality" (Wundt [1912] 1916, p. 367). As for the other two categories, the difference between them lies in the fact that the hero, "as thoroughly human, shares the universal lot of man as regards dwelling-place, length of life, and liability to sickness and death" (Wundt [1912] 1916, p. 367) whereas gods have both a human and a super-human personality; they are immortal and live in a special dwelling place, normally located outside this world. We shall not concern ourselves here with the aptness of Wundt's definition or deciding whether it is subject to the evolution of scientific knowledge on the subject. However, we can say that his definition of the hero establishes elective affinities with the footballer, seen as an emblem, as M. Maffesoli noted. 
For W. Wundt, the hero is "an idealized man" (Wundt [1912] 1916, p. 370). Football players have a series of attributes that are greatly valued socially: youth, vigour, skill, competitiveness, fame, recognition, and wealth. This fact of possessing socially-recognized virtues is what turns them into emblems, since it favors the possible expression of processes of objectivation which is ultimately what any form of idolization (hero, god, spirit, or other) points to. Footballers cannot be called spirits or gods, but here we wish to analyze whether they might be considered to be heroes of modern societies. For the moment, we consider that W. Wundt's definition to be fitting.

But what type of hero would a footballer be? And can all footballers be considered to be heroes? The answers to these two questions contain the two main paths of action we wish to explore in this section. We shall answer the first question using the genealogy and classification of the hero offered in W. Wundt [1912] (1916), updating it with the addition of a last category, and we shall discuss the second issue at greater length below. However, we believe some form of introduction is important here. First, we must introduce a small differentiation. Compared to the rest of society, the footballer is considered privileged. However, in spite of being privileged compared to a non-footballer, if we reduce the margin of action, focusing exclusively on footballers, we have seen that not all football players are heroes in the strict sense of the word. Only those who are outstanding in this socially valued art can be said to achieve this status.

Just as only one kouros could be the victor in a race in honor of Dionysus, as F. M. Cornford (1912) notes, the status of hero can only be attained by the greatest among the great. Heroism is essentially linked to achievement, to the performing of different actions, of feats. "The hero/player must be the other to be capable of inverting the same ${ }^{3 \prime \prime}$ (Verdú 1980, pp. 19-20). Thus, the football hero is that one who stands out, who does things that the rest do not, who has something that others do not. In other words, they embody an ideal. In today's footballing universe, two figures bear the sublime, Cristiano Ronaldo and Lionel Messi. Both have attained the pinnacle of their profession, but they have done so by playing sometimes radically different models or patterns. Therefore, our second line of action in this section will be to turn these two players into two archetypical categories or Weberian ideal types. This exercise should reveal two different and exclusive modes, two 'paths to be consecrated', two forms of accomplishing the hero status through the actions performed in the footballing 'field'.

\subsection{The Football Hero}

Just as M. Donald (1991) speaks of different 'stages' in human evolution, we can also follow W. Wundt [1912] (1916) in seeing different phases in the historical development of the hero. He proposes three: the hero of the sagas, the redeeming hero, and the saint hero. We shall add a fourth category, which we shall use to link the German psychologist's thinking to the subject of our study, the secular hero, one of whose representatives is the football hero.

We shall start with the saga hero. This is a kouros, but not a "lad" (Wundt [1912] 1916, p. 335). "He is a man in the prime of his life" (Wundt [1912] 1916, p. 335). Although his youth is one of his characteristic features, this freshness is not the axis around which the virtue he represents revolves. Rather, it comes from a blend of a not overly-ripe maturity and youth without inexperience. He is "a being of transcendent power and strength" (Wundt [1912] 1916, p. 336). His strength comes from his youth, but he derives his power from a combination of experience and vigor. The second category, the redeeming hero "represents an offshoot of the hero saga, springing up at those times when the religious impulses are dominant" (Wundt [1912] 1916, p. 339). In other words, just as the saga hero had played a central role in the transition from myth to logos and from magic to religion, the redeeming hero, fundamentally, is a being of religious good tidings. Likewise, the redeeming hero is "a personality who is throughout exalted above human stature, but who, nevertheless, attains to divinity only through his striving, his suffering, and his final victory." (Wundt [1912] 1916, pp. 339-40). This in turn suggests an 
other-worldly religious goal or purpose (attaining divinity), which is achieved through fundamentally human means. We believe that the strength of Wundt's classification lies in the historicity (humanity) of figures such as Jesus of Nazareth or Prince Siddhartha Gautama, rather than in their reborn or iconic versions as the 'anointed' (Christ), or the 'enlightened' one (Buddha). Thirdly, we have the figure of the saint hero. Such heroes attain sacred status without abandoning their human nature. Their achievements are related to that fact of "awakening [ ... ] to a pure religious life" (Wundt [1912] 1916, p. 340). Their actions are always confined to the sphere of the human. One might ask what the difference is between Buddha and the saints. In terms of their heroic action, there is practically none at all, as they both seek religious perfection through intervention in the everyday. However, according to M. Weber the difference lies in the fact that Siddharta was reborn (Weber [1922] 1978) as Buddha; he ended up acquiring a divine status, he is invested by the charisma, whereas saints are not.

When W. Wundt talks about heroes, he is referring to the primitive stage, yet his definition need not be limited to this phase though, which, he writes, mankind has already passed. If the hero is 'man in idealised form', in all societies we will find subjects capable of bringing essentially human skills to the sphere of the ideal. We have therefore decided to introduce a fourth type, the secular hero. A person may be considered a secular hero if, as Charles Taylor (2007) argues, he lives his life-and thus his heroic actions - in the context of an immanent frame. Here it is important not to confuse immanence with an absence of idolization. Behind the hero-like the demon or the god-one can see the ineffable, the mysterious, the tremendous, the transcendental. These aspects, which are closely linked to the sacred—as authors such as Rudolf Otto [1917] (2012) and Ingolf Dalferth (2017) have noted-have not disappeared from the scene in modern and secular societies, rather they have been transformed (Lenoir 2005), taking on different guises. According to a number of writers on the subject, such modern-secular embodiments of the sacred include the following: the person (Durkheim [1898] 1973; Joas 2014), revolutionary cults (Mathiez [1904] 2012), and the civil 'sphere' (Bellah [1967] 2007). Likewise, the sacred keeps cropping up both in the public dimension (Casanova 1994) and in the private (Luckmann 1973; Beck 2009; James [1902] 1986).

Zygmunt Bauman sees processes of individuation as the characteristic feature of modernity. “To put it in a nutshell, 'individuation' consists of transforming human 'identity' from a 'given' into a 'task' and charging the actors with the responsibility for performing the task and for the consequences (also the side-effects) of their performance" (Bauman 2000, p. 32). In this backdrop, subjects who are capable of standing out, of approaching perfection in the execution of this task acquire a different status; they become ideal men, or heroes in Wundt's terms. The status they achieve is not divine because they are still human, but this does not prevent us from identifying dynamics of immanent idolization which appear as a consequence of their achievements, of the fact of having succeeded in "a search for personal maturity and social relevance" (Bellah 1969, p. 81). For all of these reasons, we consider the modern backdrop to be a fertile terrain for heroism and for the emergence of individual religious forms, as we shall see in the following sections.

\subsection{Cristiano Ronaldo and Lionel Messi as Weberian Ideal Types}

As we have seen, both the religious and the heroic have a place in modern, secular societies. However, as we know, not all social practices afford access to heroic status in equal terms. There are some who, due to their social importance-as in the case of monotheistic religions in the phase of the 'historical religions' (Bellah 1969) or sacrifice in agro-pastoral societies (as Marcel Hénaff (2010) notes) - facilitate the transition along and towards the 'paths of consecration'. To-day, sport in general and football in particular help to fulfil that function, essentially because of the importance they have attained as symbols of the civilizing process (Elias and Dunning 1992), as guarantors of controlled violence, shifted into a form of leisure-in short, into something very closely associated with regulated play, with the game.

As we have said, in today's footballing universe, two players stand above the rest, Cristiano Ronaldo and Lionel Messi. Although both can be said to have triumphed in the idolizing modern 
task of achieving social relevance through the exemplary exercise of their profession, each exemplifies a different way of acquiring hero status. Here it may be helpful to objectify their different defining attributes by referencing two Weberian ideal types (Weber [1922] 1978). For the moment, then, we shall turn away from specific footballers and seek to describe and investigate two (also specific) means of attaining heroic status in modern societies, in this case through the game of football. We shall divide this task into three phases. Firstly, we shall apply the Nietzschean dialectic between the Apollonian and the Dionysian to these two players, and secondly, we shall clothe Cristiano Ronaldo in the garb of the ascetic and Lionel Messi in that of the trickster. Finally, we shall explore how their numbers ( 7 and 10 respectively) also offer relevant information on their attributes and the 'paths of consecration' they have travelled.

In The Birth of Tragedy (Nietzsche [1872] 1980), Friedrich Nietzsche presents two "spirits" (Nietzsche [1872] 1980, p. 24), which commonly clash dynamically in social life and which are key for explaining how mythical-archetypical genus arises. These are the Apollonian (linked to the Greek god Apollo) and the Dionysian (associated with Dionysos). Our interest here is not in analyzing the tension between these two 'forces' or 'spirits', but in associating each of them with one of the two players we are studying. Cristiano Ronaldo represents the Apollonian spirit expressed through the element of wilfulness. Through this capacity, which combines decision, intention, and sacrifice, he builds order, harmony, and a "monument of achievements" (Nietzsche [1872] 1980, p. 39). Cristiano Ronaldo is an example of wilfulness, of 'professionalism' placed at the service of football. He is the first to arrive at the training sessions and the last to leave. He has sculpted each of his muscles to get the most from it, to place it at the service of his profession and to extend his sporting career to the maximum. His will for perfection, to continuously reinvent himself, has led to success and the heroic path. He is unquestionably a self-made man. Lionel Messi, on the other hand, embodies the Dionysian spirit. Despite the undeniable will, effort, and professionalism, which he brings to his task, his fundamental 'strength' lies not in these features, but in the innate. Messi seems driven-intoxicated, even-by a force, which, by definition, lies outside his capacity to control it, which goes beyond his will. That force chose him long before he himself learned to handle it. Indeed, it is his capacity to control it that makes him a magician (Weber [1922] 1978). This strength is very closely linked to the Weberian charisma (Weber [1922] 1978) or the mana that Mauss [1924] (1979) analyzes.

We can see elective affinities between these aspects and the second pair of concepts through which we shall construct the ideal types embodied by Cristiano Ronaldo and Lionel Messi, the worldly ascetic and the trickster. Cristiano Ronaldo is the maximum representative of worldly asceticism oriented towards football. For M. Weber, "The person who lives as a worldly ascetic is a rationalist, not only in the sense that he rationally systematizes his own conduct, but also in his rejection of everything that is ethically irrational, aesthetic, or dependent upon his own emotional reactions to the world and its institutions. The distinctive goal always remains the alert, methodical control of one's own pattern of life and behaviour" (Weber [1922] 1978, p. 544). As we saw in the last paragraph, Cristiano Ronaldo applies a rational method for steering his life towards the achievement of his goals. His 'alert control' and method-based approach are key to understanding his achievements. Lionel Messi, in contrast, is no worldly ascetic. His heroic status is associated with certain specific aspects of another archetype, analyzed in depth by authors such as Carl G. Jung [1954] (2005), Emmanuel Lizcano (2018), and Paul Radin (1972), the trickster. Although C. G. Jung [1954] (2005, p. 248) stresses the unconscious (a notion which, as we have seen, is very closely linked to the Dionysian element), the area of greatest coincidence between the figures of Lionel Messi and the trickster is in the aspect of the "sower of chaos" (Lizcano 2018, p. 2). Lionel Messi specializes in creating chaos in his adversaries' defensive systems, in resorting to the unpredictable or to the never-before-seen to 'mock' his enemies. His capacity to disrupt and the ease with which he achieves it are two of his clear defining features. Even his name 
might seem to presage his archetypical condition, he is Lio (mess in Spanish)-nel Mess-i, in other words, a double generator of chaos. "He is a disrupter" (Lizcano 2018, p. 10).

Cristiano Ronaldo's shirt number is 7, and Messi's is 10. In the imaginary of football, 7 is reserved for the forwards, for the strikers or goal-scorers, whereas 10 is for mid-fielders. Historically it has been associated with footballers with exceptional technique, men who have brought something different and novel to the game. They are normally more the creators of goals than the scorers. At the same time, it is interesting to examine briefly at the symbolic value these two numbers have in the specific imaginary of Real Madrid and Barcelona. Real Madrid has forged its character and much of its identity on its number 7s. They have been representatives of effort, of determination, and of never giving up on a ball or a match, in short, of attaining their achievements through absolute commitment. That is the recipe behind their winning nature and what 'sets their fans alight'. Apart from Cristiano Ronaldo, two other key players have worn this number, Juan Gómez 'Juanito' and Raúl González Blanco. No other shirt has such a symbolic charge as Real Madrid. As we see, there is a communion between the attributes with which we have defined Cristiano Ronaldo, the symbolism of the number, and the identity of the club. In the case of Barcelona, the dynamic is different. We would not go so far as to say that the number 10 has the same symbolic role as the 7 in Real Madrid, but if we look at some of the players who have worn the short-Diego Armando Maradona, Romario, Rivaldo, Ronaldinho, and of course Lionel Messi himself-we can see that it has certainly had a specific weight in the creation of Barça's history and, therefore, in the forging of its identity. Barcelona's followers particularly appreciate this type of refined, high-quality player. Indeed, this type of player fits very well into the passing game and a mastery of ball possession that characterizes the team. Real Madrid's style, on the other hand, is closer to a stampede, intensity and speed, catharsis.

Cristiano Ronaldo and Lionel Messi are both representatives of the secular hero, but we can see some analogies between them and Wundt's prototypes (Nietzsche [1887] 1990). Cristiano Ronaldo is more of a saintly hero, whose deeds in the world (like the 'good Protestant' of the story) has afforded him holy status, while Lionel Messi is a redeeming hero, touched by the magic wand of charisma. Both have affinities with the saga hero, they are men in the 'prime of their life', superior to their fellow footballers and to other mortals through their attainment of heroic status.

\section{The Religious in Football Video Games}

Having set out some of the keys that will enable us to examine football from a religious perspective or from the point of view of the creation of sacredness, in this section we shall go one step further, extrapolating this analysis to the universe of football video games. We shall start by briefly considering the world of the video game in general. We shall then go on to explore whether we can find any mechanism of idolization linked to the playing of football video games.

\subsection{The Game of the Game}

According to the Spanish Video Game Association $\left(\mathrm{AEVI}^{5}\right)$, the video game market grew worldwide by $8.5 \%$ in 2016 and now has global sales of 99.6 billion dollars. Europe is an industry leader and Spain is among the ten countries with the highest consumption of video games on the continent. Video games are the leading audio-visual leisure activity in Spain. Spaniards spend $6.2 \mathrm{~h}$ a week playing video games. And another relevant statistic is that the top-selling video game in Spain in 2016 was FIFA 2017, rising from eleventh place in 2015 for the previous year's version. In January 2018, FIFA (2018) is still the country's top seller. The subject matter is football.

This is a suitable juncture to focus on the fundamental aspect of this section. What do we seek to draw from this reflection? That video games, viewed as a game of the game, represent a new phase in the process of culture creation. In his Homo Ludens, J. Huizinga argues that "culture arises in the form of 
play, that it is played from the very beginning" (Huizinga [1949] 1980, p. 46). If we add both his own analysis on the recreational genesis of culture and the schemas for understanding social evolution provided by N. Elias [1939] (1968) and M. Donald (1991), we can see that—like culture—play adopts increasingly complex forms as it evolves. That greater complexity inherent to the creation of culture and society is what led to the rise of second-order thinking in Ancient Greece-in the context of the Axial Age-as Yehuda Elkana (1986) has shown.

Both the historical development of play - the associated incorporation of complexity-and the importance it has acquired in today's societies, can be said to have led to the emergence of a dynamic that parallels the expression of second-order thinking. This dynamic does not so much stress reflexivity (that is to say, a logic centring on thinking the game), but another logic in which a second-order game emerges, based on a previous game. This second-order game, played on or over itself, is magnificently exemplified by the football video game.

\subsection{The Football Video Game as a Bridge between the Sacred and the Secular}

N. Elias and E. Dunning remark that "what humans seek in their mimetic recreational activities is not to release tension but rather to experience a specific type of tension, a form of excitement which, as St Augustine clearly understood, is often associated with fear, sorrow and other emotions we try to avoid in our everyday life" (Elias and Dunning 1992, p. 106). This statement echoes the fine distinction drawn by É. Durkheim [1912] (1965) between sacred and profane states. Through mimetic and later symbolic recreational activity, the person who leads their 'everyday life' in the profane state gains access to the sacred state. This quote highlights the mediating role of play as a nexus, serving as a vehicle permitting travel between the spheres identified by É. Durkheim. Play can therefore have the same function of communication that was played by sacrifice (Hénaff 2010). Sacrifice might therefore be described as a 'sacred game', a term used by J. Huizinga [1949] (1980). However, what we are trying to elucidate is not whether we can find 'sacred games' (we believe this has been sufficiently proven) but rather whether behind football video games we can find that horizon of sacredness that so clearly lay behind sacrifice.

The first thing we should note is that video games in general and football video games in particular are not video-plays but video-games. Playing a game, as G. H. Mead [1934] (1962) notes, implicitly involves the interiorization of a 'generalized other', of a set of rules and guidelines for collective action. The game is always played with others (regardless of in this game the main contest in being played by a real player and a virtual player). Both the sacred game and the video game are always games, not play. G. H. Mead argues that there are "certain rites that are a representation of what supposed gods and heroes to do" (Mead [1934] 1962, p. 153). Although a player who switches on their Play Station or X-Box and sits down in front of the screen to 'control the movements' of the players need not necessarily be recreating an action that has taken place in the past, nonetheless what is depicted might perfectly well have happened or happen. What they experience is a simulation of a match, showing the electronic fortunes and misfortunes of real footballers, designed to be as faithful as possible to their originals, in terms of their physical appearance and skill sets. They are created in this way so that the experience is as real as possible.

However, although every sacred game is a dromenon (i.e., it is enacted), as we argue in Section Two (sic J. Huizinga), not every representation bears the hallmarks of the sacred. We must therefore use another key if we wish to establish effectively a connection between the sacred/religious and football video games. The Dutch historian writes, "The rite, or 'ritual act' represents a cosmic happening, an event in the natural process. The word 'represents', however, does not cover the exact meaning of the act, at least not in its looser, modern connotation; for here 'representation' is really identification, the mystic repetition or re-presentation of the event" (Huizinga [1949] 1980, pp. 14-15). For Huizinga the key that turns a representation into a sacred game is that through it a process of mediation between the sacred and the secular is produced. We believe that this identification also occurs in the performance that occurs in the football video game, which we shall analyze using two formulas. 
Firstly, the digital game allows the player to virtually control the threads of existence. The game allows them to become an agent capable of controlling all aspects involved in the action, a demiurge. By doing this, they can decisively influence the result. By controlling the game of the game, they become the symbolic dominator of the world of football. Through this action, which occurs as a result of the virtual play, the player accedes to a state that would be off-limits to him in his condition as a secular subject. In this way, he transcends his limited human nature. So the player of the videogame has an enhanced personality, a technically increased control of the game. Secondly, the game of the game is a mechanism of intermediation through which the player becomes the footballer he is controlling. These two formulas of symbolic and virtual identification refer back to an essentially quasi-religious horizon.

So, whether through the video game the player becomes a demiurge or whether, he wears the mask of the hero, just like a religious ritual, the identification lasts as long as the performance is played out. During this time, the player changes state. This state is conceived as "a totius substantiae transformation" (Durkheim [1912] 1965, p. 54), something which É. Durkheim links to the sacred state. For, through the video game, they experience a renaissance (Weber [1922] 1978). Even if it is limited to the time in which the action takes place, it is no less religious than those in which that temporary state becomes permanent, such as the pope's change of name on acceding to the throne of St. Peter. They appear "under a new form" (Durkheim [1912] 1965, p. 54) —in this case that of the icon they operate via the controls or the demiurge capable of changing the sequence of things-while he is 'filled' with the sacred.

\section{Discussion}

In short, although, as J. Huizinga [1949] (1980) notes, over time the game has been gradually stripped of its sacred nature, we have shown how some of the elements involved in football video games can be analyzed in terms of the sacred. This does not mean that football video games can be said to be a religion; that would exceed our arguments here. However, it does mean that we can see certain dynamics in them that point towards the religious. These dynamics, as we have explained, have a transcendental component understood as an 'individualized reconnection'. This idea was magnificently expressed by Ernst Troeltsch, who created a religious category to complement the classic classifications of Church and Sect, i.e., mysticism. According to this notion "The world of ideas which had hardened into formal worship and doctrine is transformed into a purely personal and inward experience" (Troeltsch [1911] 1931, p. 992). É. Durkheim pointed out the same idea in this paragraph, "Not only are these individual religions very frequent in history, but nowadays many are asking if they are not destined to be the pre-eminent form of the religious life, and if the day will not come when there will be no other cult than that which each man will freely perform within itself" (Durkheim [1912] 1965, p. 61). This category, which has been widely used in subsequent studies in the area of human and social sciences (Luckmann 1973; Warner 2005; Beck 2009), perfectly identifies the religious process that occurs in the game of the game of football. In this type of religiosity, we do not encounter gods to be emulated, but living heroes/icons with whom to identify, such as Cristiano Ronaldo and Lionel Messi, who, like Hercules and Achilles, are not gods.

J. Huizinga [1949] (1980) also tells us that culture originates and develops in and through play. This means that religion, seen from the perspective of a sacred game, is one of the first complex forms in which the game was embodied, following its primitive and infantile phase as play. Arising out of this consideration, perhaps, over and above the religious component associated with football video games, we should note that the fundamental aspect of these games of games is, evidently, that they are played. Having said this, we believe that it would be very wrong to consider that the forms that appear after the stage of the sacred game are necessarily stripped of elements of sacredness. This would be to misunderstand the importance of Merlin Donald's (1991) analyses in understanding both our own thesis and the evolution of societies. 
In this order of things, the reflection on the religious character of the virtual videogame is closer to the model of privatized religion, in Troeltsch [1911] (1931) and Luckmann's (1973) terms. We talk about a religious experience, which does not need the hot, thick, atmosphere of the rituals performed above and explained mainly by Durkheim. The individual would be the producer and the product, the God and believer at once, of a religious experience in which there is no break-up with the daily world. The religious experience of the virtual videogame does not match with the definitions of religion made by Clifford Geertz (1993) and Robert N. Bellah (2011) in which the main features are the ritual enhancement of the collective life linked to a general order of life.

In the videogame, or game on the game, the enhanced collective emotions of the real football game vanished being substituted by an identification game of the real player with the virtual player in a sort of mimesis where the former tries to be like the later, where a process (a neo-magical or new age process, we might say) of privatization of emotions is mobilized. This process arises within the new digitalized societies where the ritual dimension is hidden and where the public, the spectator, is missed, and where the dimension of the actor-player and the actor-public are substituted by an isolated real actor-player who interacts with a virtual actor-player, with an avatar, in a sort of each other mirroring play in which they mirror themselves ad infinitum. The playing field shifts into a screen in which the player (oneself) is a double of his idol and there is not anymore the public, the outside spectator, but another player (virtual), which is the main star of a game on the game. The play is been played between two players mainly, one real and the other virtual, and the first tries to be like the second.

Author Contributions: Conceptualization, J.G.-G., J.B., C.S.-C.; Methodology, J.G.-G., J.B., C.S.-C.; Software, J.G.-G., J.B.; Validation, J.G.-G., J.B., C.S.-C.; Formal Analysis, J.G.-G., J.B., C.S.-C.; Investigation, J.G.-G., J.B., C.S.-C.; Resources, J.G.-G., J.B., C.S.-C.; Data Curation, J.G.-G.; Writing-Original Draft Preparation, J.G.-G., J.B., C.S.-C.; Writing-Review \& Editing, J.G.-G., J.B., C.S.-C.; Visualization, Javier Gil-Gimeno, J.B.; Supervision, J.G.-G., J.B., C.S.-C.; Project Administration, J.G.-G., J.B., C.S.-C.

Conflicts of Interest: The authors declare no conflict of interest.

\section{References}

Bauman, Zygmunt. 2000. Liquid Modernity. Cambridge: Polity Press.

Beck, Ulrich. 2009. El Dios Personal. Barcelona: Paidos.

Bekoff, Marc, and Pierce Jessica. 2009. Wild Justice. The Moral Lives of Animals. Chicago: Chicago University Press.

Bellah, Robert N. 1969. Religious Evolution. In Sociology and Religion. Edited by Norman Birnbaum and Gertrud Lenzer. Upper Saddle River: Prentice-Hall, pp. 67-83.

Bellah, Robert N. 2007. Religión Civil en América. In Las Contradicciones culturales de la modernidad. Edited by Josetxo Beriain and Maya Aguiluz (coords.). Barcelona: Anthropos, pp. 114-38. First published 1967.

Bellah, Robert N. 2011. Religion in Human Evolution. From the Paleolithic to the Axial Age. Cambridge: The Belknap Press of the Harvard University.

Beriain, Josetxo. 2015. Genealogía afirmativa' del hecho religioso en perspectiva sociológica. Revista Española de Investigaciones Sociológicas (REIS) 151: 3-22.

Casanova, José. 1994. Public Religions in the Modern World. Chicago: Chicago University Press.

Collins, Randall. 2004. Interaction Ritual Chains. Princeton: Princeton University Press.

Cornford, Francis M. 1912. The Origin of the Olympic Games. In Themis, a Study of the Social Origins of Greek Religion. Edited by Jane E. Harrison. Cambridge: Cambridge University Press, pp. 212-59.

Dalferth, Ingolf. 2017. Trascendencia y mundo secular. Salamanca: Sígueme.

Donald, Merlin. 1991. Origins of the Modern Mind. Three Stages in the Evolution of Culture and Cognition. Harvard: Harvard University Press.

Dress, Ludwig. 1968. Olympia. Gods, Artists and Athletes. London: Pall Mall.

Dunning, Eric. 2009. Figurational Sociology and the Sociology of Sport. In Sociology of Sport and Social Theory. Edited by Earl Smith. London: Human Kinetics, pp. 143-53.

Durkheim, Émile. 1973. Individualism and the Intellectuals. In Émile Durkheim on Morality and Society. Edited by Robert N. Bellah. Chicago: Chicago University Press, pp. 43-58. First published 1898. 
Durkheim, Émile. 1965. The Elementary Forms of Religious Life. New York: The Free Press. First published 1912.

Elias, Norbert. 1968. The Civilizing Process. Sociogenetic and Psychogenetic Investigations. London: Blackwell. First published 1939.

Elias, Norbert, and Eric Dunning. 1992. Deporte y ocio en el proceso de la civilización. México: Fondo de Cultura Económica.

Elkana, Yehuda. 1986. The Emergence of Second-order Thinking in Classical Greece. In The Origins and Diversity of Axial Age Civilizations. Edited by Shmuel N. Eisenstadt. New York: State University of New York Press, pp. 40-64.

Fukuyama, Francis. 2018. The Last English Civil War. Daedalus 147: 15-25. [CrossRef]

Geertz, Clifford. 1993. Religion as a cultural system. In The Interpretation of Cultures: Selected Essays. Geertz: Fontana Press, pp. 87-125.

Gehlen, Arnold. 1980. El hombre. Salamanca: Sígueme.

Gopnik, Alison. 2009. The Philosophical Baby. What Children's Minds Tell Us about Truth, Love, and the Meaning of Life. New York: Farrar, Strauss and Giroux.

Harrison, Jane E. 1912. Themis. A Study of the Social Origins of Greek Religion. Cambridge: Cambridge University Press. Hénaff, Marcel. 2010. The Price of Truth. Standford: Standford University Press.

Huizinga, Johan. 1980. Homo Ludens. A Study of the Play-Element in Culture. Boston: Routledge and Kegan Paul. First published 1949.

James, William. 1986. Las variedades de la experiencia religiosa. Barcelona: Península. First published 1902.

Joas, Hans. 2014. The Sacredness of the Person. Georgetown: Georgetown University Press.

Jung, Carl G. 2005. Acerca de la psicología del trickster. In Los arquetipos y lo inconsciente colectivo. Madrid: Trotta. First published 1954.

Lenoir, Fréderic. 2005. Las metamorfosis de dios. La nueva espiritualidad occidental. Madri: Alianza.

Lizcano, Emmanuel. 2018. El trickster o la burla recreativa. In Lo demónico, el duende y el daimon. Edited by Luis Garagalza. Barcelona: Anthropos, Aceptado, en proceso de edición.

Luckmann, Thomas. 1973. La religión invisible. Salamanca: Sígueme.

Maffesoli, Michel. 2009. Iconologías. Nuestras idolatrías postmodernas. Barcelona: Península.

Mathiez, Albert. 2012. Los Orígenes de los cultos revolucionarios. Madrid: CIS. First published 1904.

Mauss, Marcel. 1979. Sociología y antropología. Madrid: Tecnos. First published 1924.

Mead, George H. 1962. Mind, Self and Society from the Standpoint of a Social Behaviorist. Chicago: University of Chicago Press. First published 1934.

Nietzsche, Friedrich. 1980. El Origen de la tragedia. Buenos Aires: Adiax. First published 1872.

Nietzsche, Friedrich. 1990. Genealogía de la moral. Madrid: Alianza. First published 1887.

Otto, Rudolf. 2012. Lo santo. Lo racional y lo irracional en la idea de dios. Madrid: Alianza. First published 1917. Oxford Dictionaries. 1992. Concise Oxford Dictionary of Current English. Oxford: Oxford University Press.

Plato. 1980. The Laws. New York: Basic Books.

Radin, Paul. 1972. The Trickster. A Study in American Indian Mithology. New York: Schocken Books.

Rigauer, Bero. 1969. Sport und Arbeit. Frankfurt: Suhrkamp.

Stone, Gregory P. 1971. American Sports: Play and Dis-play. In The Sociology of Sport: A Selection of Readings. Edited by Eric Dunning. London: Cass.

Taylor, Charles. 2007. A Secular Age. Cambridge: The Belknap Press of Harvard University Press.

Troeltsch, Ernst. 1931. The Social Teachings of the Christian Churches. London: Allen and Unwin. First published 1911. Verdú, Vicente. 1980. El fútbol. Mitos, ritos y símbolos. Madrid: Alianza.

Warner, R. Stephen. 2005. A Church of Our Own: Disestablishment and Diversity in American Religion. New Brunswick: Rutgers University Press.

Weber, Max. 1978. Economy and Society. Los Angeles: University of California Press. First published 1922. Wittgenstein, Ludwig. 1988. Investigaciones filosóficas. Ciudad de México: UNAM-Crítica. Wundt, Wilhelm. 1916. Elements of Folk Psychology. London: George Allen and Unwin. First published 1912.

(C) 2018 by the authors. Licensee MDPI, Basel, Switzerland. This article is an open access article distributed under the terms and conditions of the Creative Commons Attribution (CC BY) license (http:/ / creativecommons.org/licenses/by/4.0/). 